\title{
A Teaching Suggestion in the COVID-19 Disease Pandemic Period:
} The Educational Website Enriched by Web 2.0 Tools

\author{
Mehtap Yildirim, Marmara University, Turkey \\ Lerna Gurleroglu, Ministry of National Education, Turkey
}

\begin{abstract}
The effect of the COVID-19 pandemic shows that schools must adapt new approaches in order to continue to provide teaching and learning at schools. To achieve this, students must be equipped to learn in a multifaceted, multitasking, and technology-driven world, and the utilization of Web 2.0 tools has been revealed as important in this endeavor. The aim of this study is to introduce an educational website enriched with Web 2.0 tools designed for science teaching and in addition to show the effect on achievement and motivation. Therefore, the effect of an educational website supported by Web 2.0 tools on achievement and motivation was investigated in a quasi-experimental design with a pretest-posttest control group. The unit of "Force and Energy" was presented through an educational website enriched by Web 2.0 tools. The positive effects of using the website on the achievement and motivation of the students in the results brought to mind the use of an educational website supported by Web 2.0 tools as an alternative or support to online training during the COVID-19 pandemic.
\end{abstract}

\section{KEYWORDS}

5E Learning Model, Academic Achievement, Educational Website, Motivation, Science Teaching and Learning, Web 2.0 Tools

\section{INTRODUCTION}

The COVID-19 pandemic has shown people that in order to maintain the process of teaching and learning, schools must adapt to these changing conditions. Uncertainties regarding what will happen in the near future and how long this situation will continue remain. Therefore, authorities are looking for alternative education to create a sustainable situation. Nowadays, the development of information and communication technologies (ICT) and that these technologies are easily prepared have influenced all fields, including education (Mališů \& Šaloun, 2020). Technology already has been used in education over many years, and now online education has begun to occupy a more significant place than ever. Due to the COVID-19 pandemic, existing education systems around the world have been suspended and a move toward online distance education has started. This means that students must be equipped to learn in a multifaceted, multitasking, and technology-driven world. 


\section{LITERATURE REVIEW}

\section{WEB-2.0 TOOLS}

The internet has several critical roles in education as a learning environment. In the early days, the internet and particularly the web were a fixed structure, because there were no active viewers (Kaldoudi, Bamidis, Papaioakeim \& Vargemezis, 2008). With the development of computer and internet technologies, web service has improved, and an important example of this is Web 2.0 tools, particularly as an approach to the delivery of education. The term social software is applied to Web 2.0 tools since they promote the switch from web readership to web literacy (Cin Şeker, 2020).

The concept of Web 2.0 was first used by Darcy Di Nucci in 1990, but it was O'Reilly and Dale Dougherty who popularized it in the following years (Moshahid \& Pt, 2017). In 2003, O'Reilly Media referred to a new term called Web 2.0, which allowed easier sharing of information on internet. Social media applications, such as YouTube, MySpace, Facebook, Flickr, and Twitter, are examples of Web 2.0 technologies (Peltier-Davis, 2009). Briefly, the dynamic structure of Web 2.0 creates web technologies that are widely used today, providing fast and easy access to information, and offering information production opportunities (Çekinmez, 2009). Web 2.0 is not an upgrade of Web 1.0; it is a set of new technologies, tools and services that support group and community activities. The user is no longer a recipient, but a participant (Kaldoudi, Bamidis, Papaioakeim \& Vargemezis, 2008). The next-generation Web 2.0 presents matchless opportunities for teaching and learning applications in the areas of collaboration, communication, inquiry, literacy, and personal expression (Drexler, Baralt, \& Dawson, 2008). Web 2.0 tools are very important for teaching and learning, allowing students to learn better in school (Moshahid \& Pt 2017). Web-based learning environments can be used as motivation, teaching, modeling, feedback and evaluation tools (Wijekumar, 2005). Web 2.0 tools ensure great occasions for education (Konstantinidis, Theodosiadou \& Pappos, 2013), yet their application appear to be underused by teachers (Elmas \& Geban, 2012). In addition, teaching with Web 2.0 tools provides students and teachers with a better chance of communicating, with teachers also being able to give their students quick feedback (Halili, 2018). By supporting learning as an enjoyable and experimental approach, Web 2.0 tools also offer students the opportunity to work outside school. In addition, with supporting interactive and collaborative activities, students are given learning environments suitable for the digital age (Olea, 2019). Today, people can easily engage in learning by inter connecting without time and place constraints due to the progress in information and communication technologies (Genç, 2010). Using of Web 2.0 tools in education is important, because of that Web 2.0 tools can be used to improve new learning strategies that can increase student motivation, participation, self-directed learning and simplify learning (Redecker, Punie \& Mutka, 2008).

The results obtained from studies using Web 2.0 tools in education have shown that teaching with Web 2.0 tools is more successful than traditional methods, providing collaborative and active learning and increasing students' learning (Huang, Hood \& Yoo, 2013; Baig, 2011; Bayrak Karadeniz \& Bayram, 2012; Akgün, Özden, Çinici, Aslan \& Berber, 2014; Ballıel Ünal, 2017; Karagöz \& Korkmaz 2015; Çetin \& Günay, 2010; Canan Güngören, 2019; Buluş Kırıkkaya, Dağ, Durdu \& Gerdan, 2016; Ureña-Torres, Tenesaca-Luna, Arciniegas \& Segarra-Faggioni, 2017), and web-based teaching and using of web 2.0 tools in education have positive effects on student motivation (Wang \& Reeves, 2007; Balaman \& Tüysüz, 2011; Akgündüz \& Akınoğlu, 2017; Karahan \& Roehrig, 2016; Durovic, Dlab \& Hoic-Bozic, (2018).

\section{Aim Of The Study}

In the past years, online education was not preferred by teachers and students. The 2019 coronavirus disease pandemic (COVID-19) has particularly affected education and the economy in all countries (Rajab, Gazal, \& Alkattan, 2020). At present, almost all countries carry out online education. But, in 
this process, it was observed that a significant number of teachers did not have sufficient information technology knowledge, therefore, online teaching remains relatively weak. Due to sudden online teaching, teachers are faced with problems such as how to organize online lessons, how to conduct teaching, how to choose the teaching platform, how to ensure the impact and quality of online teaching (Chen, Peng, Yin, Rong, Yang, \& Cong, 2020). It is thought that this study will contribute to the field in terms of presenting an example of a website enriched with web 2.0 tools in order to solve the problems faced by teachers due to sudden online teaching. In addition, today, students spend most of their time surfing the internet, which raises the question of how this interest can be directed toward planned and targeted learning. Based on this question, in this article, we focus on teaching force and energy with an educational website enriched web 2.0 tools for pupils of secondary school. The topic of force and energy was selected because it is difficult to learn this subject for middle school children. For teaching this difficult subject more easily, it was decided to use an educational website where the students could spend as much time as they wanted and the responsibility of learning would be on themselves but the main control would be on the teacher. Because, Websites, which are an important example for web-based teaching, have a significant place in education (Dinc, 2017).

The educational site prepared by the teacher with Web 2.0 tools (Pixton, Bubble, Kahoot, Quizlet, etc.) was designed for the students to easily access the course resources, to communicate with their friends and teachers, and to have fun learning with educational games. This designed site was used for science teaching during face-to-face education, and the students were provided access to this website before and after the lesson. In this way, teaching was moved out of the classroom without time limit. Firstly, aim of the research is to investigate the effect of the use an educational website supported by Web 2.0 tools in the "Force and Energy" unit on students" achievement and motivation to learn science. In addition, secondly, aim of the research is to present an educational web site with enriched web 2.0 tools. For this purpose, the findings obtained in the research can;

$\square$ provide support and present an alternative to online education frequently discussed today,

$\square$ contribute to the related literature in terms of science teaching,

$\square$ be an example for teachers who want to use Web 2.0 tools in science education and can encourage them to use.

\section{Research Question}

In this context, answers to the following question;

RQ: Do the Web 2.0 tools used for the "Force and Energy" unit of the seventh-grade science course have an impact on students' academic achievement and motivation toward science learning?

\section{METHODOLOGY}

\section{RESEARCH DESIGN}

This research investigated the effect of science teaching in accordance with a 5E (Engage, Explore, Explain, Elaborate, and Evaluate) model enriched by web 2.0 tools on the achievement and motivation of seventh-grade students. A quantitative research model was chosen, and a quasi-experimental design model with pre-test-post-test control group was used, with one class being randomly determined as the experimental group and the other as the control group (Büyüköztürk, Çakmak, Erkan Akgün, Karadeniz \& Demirel, 2013). In experimental studies, the effect of one independent variable on one or more dependent variables is investigated by researchers (Cohen, Manion \& Morrison, 2000). In the experimental group, the Force and Energy unit was presented within the current curriculum 
Table 1. Experimental design

\begin{tabular}{|l|l|l|l|}
\hline \multicolumn{1}{|c|}{ Groups } & \multicolumn{1}{c|}{ Pre-test } & \multicolumn{1}{c|}{ Experimental manipulation } & \multicolumn{1}{c|}{ Post-test } \\
\hline $\begin{array}{l}\text { Experimental } \\
\text { Group }\end{array}$ & $\begin{array}{l}\text { Academic achievement test } \\
\text { Scale of motivation towards } \\
\text { science learning }\end{array}$ & $\begin{array}{l}\text { Current science curriculum } \\
\text { supported by Web 2.0 tools }\end{array}$ & $\begin{array}{l}\text { Academic achievement test } \\
\text { Scale of motivation toward } \\
\text { science learning }\end{array}$ \\
\hline $\begin{array}{l}\text { Control } \\
\text { Group }\end{array}$ & $\begin{array}{l}\text { Academic achievement test } \\
\text { Scale of motivation towards } \\
\text { science learning }\end{array}$ & $\begin{array}{l}\text { Current science curriculum } \\
\text { without Web 2.0 tools }\end{array}$ & $\begin{array}{l}\text { Academic achievement test } \\
\text { Scale of motivation toward } \\
\text { science learning }\end{array}$ \\
\hline
\end{tabular}

enriched by Web 2.0 tools with the same unit being given to the control group according to the current curriculum but without the use of Web 2.0 tools. In both groups, lessons were carried out according to the 5E learning model. Pre-tests and post-tests were applied to both groups. The experimental design is given in Table 1.

\section{Participants}

The study group of the research consisted of 48 students studying at the seventh grade at a public secondary school in Istanbul, Turkey in the academic year of 2018-2019. The sample was selected using the convenient sampling method with the teacher being one of the researchers. The selection of participant was not random for this work but a semi-experimental design (Creswell, 2008). There were two groups in the study and then the groups were selected randomly as an experimental and a control group. The experimental group $(n=23)$ consisting of 12 girls and 11 boys and the control group $(n=25)$ comprising 15 girls and 10 boys. Both groups were at the same intermediate level of academic achievement.

\section{Implementation Process}

The study was conducted with two groups: experimental and control. The application was implemented in the science course in the spring semester of the academic year of 2018-2019, with both groups attending the lessons over six weeks.

\section{Implementation Process Of Experimental Group}

First, the website Science World (https://lerna91.wixsite.com/scienceworld) was prepared by the researchers using the https://www.wix.com/ site, which has been designed in accordance with the 5E model. The 5E learning model was preferred in the study because the Turkish science curriculum relies on inquiry-based teaching (MoNE, 2018) and the 5E learning cycle provides more benefits for students' scientific research skills compared to traditional teaching models (Bybee, 2009). In addition, the 5E Teaching Model is one of the best models based on cognitive psychology, constructivist learning theory, and best practices in science teaching that can be used in a science class (Duran and Duran, 2004). In addition, in the literature, there are studies showing that giving the activities performed with Web 2.0 tools with 5E learning model is more effective. Özenç, Dursun and Şahin (2020) investigated the effects of activities developed with WEB 2.0 tools based on the 5E learning cycle model on mathematical achievement in elementary school. As a result, they stated that the activities developed with WEB 2.0 tools with 5E learning cycle used in experimental groups were more effective than WEB 2.0 activities developed without using the 5E learning cycle model on achievement of students.

In this implementation, the aim is to present two science teaching program acquisitions in three lesson hours (total 120 minutes). Web 2.0 tools, such as Kahoot, Prezi, Google Form, Quizlet, Pawton, Bubble, Popplet, and Toondoo were used to create the activities used in the implementation. The six-week experimental application process was undertaken with face-to-face education in the 


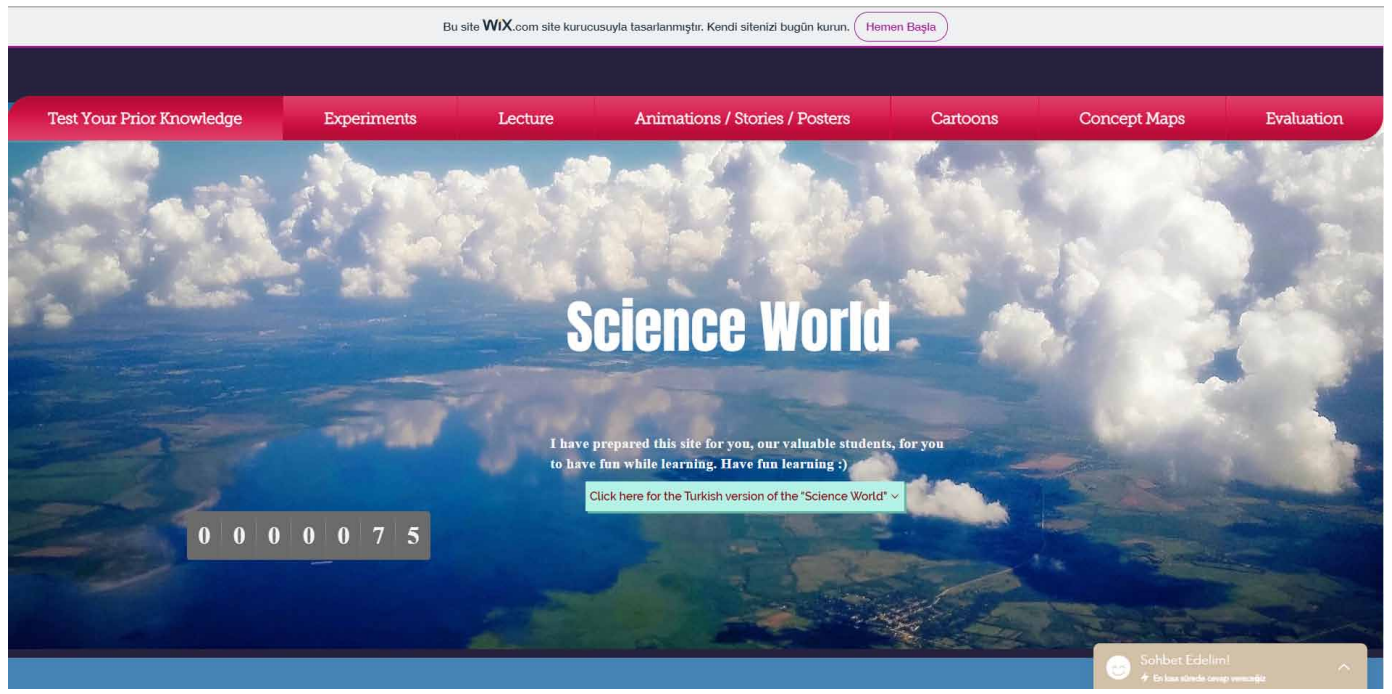

classroom. The science teaching supported by Web 2.0 tools was carried out in the classroom, and the website prepared by researchers that students could access out of school was used as a digital education environment. In addition to Web 2.0 tools, textbooks, educational platforms, such as Morpa Campus and the Education Information Network (EBA in Turkish), drama, and discussion activities were also used.

\section{Sample Lesson Plan}

\section{Engage}

In the engage phase, first, access to the prepared course materials is provided on the website (https:// lerna91.wixsite.com/scienceworld). The screenshot of the homepage is given in figure 1 .

Second, clicking on the "Force" tab in the "Test Your Preliminary Knowledge" section, questions created on google forms (https://forms.gle/fdU27GtCCuzzHfwA8) are presented to students and the pre-knowledge about the subject of Force is determined, and then by clicking on the "Animations / Stories / Posters" section, the "Avanak Avni's Bad Luck" tab (Figure 2) opens and students can watch the animation about gravity on the website (https://www.powtoon.com/c/d5DaSxFe1gt/0/m). Finally, questions about the animation are discussed and the engage phase is completed.

\section{Explore}

In the explore phase, first, clicking on the "Weight" tab in the "Experiments" section opens (Figure 3) a page (https://www.powtoon.com/c/gb2QCQzEcCK/0/m), where students can undertake the experiment in the animation to learn that the objects have weight. Finally, the answers to the questions asked during the engage phase can be found in the explore phase.

\section{Explain}

In the explain phase, first, clicking on the "Lecture" section and then the "What is Weight?" tab (Figure 4) opens a page, in which the subject related to the weight is given with the Prezi presentation (https://prezi.com/b3ajlokxuzp9/weight/?utm_campaign=share\&utm_medium=copy). 
Figure 2. Screenshots of animation "Avanak Avni's Bad Luck"
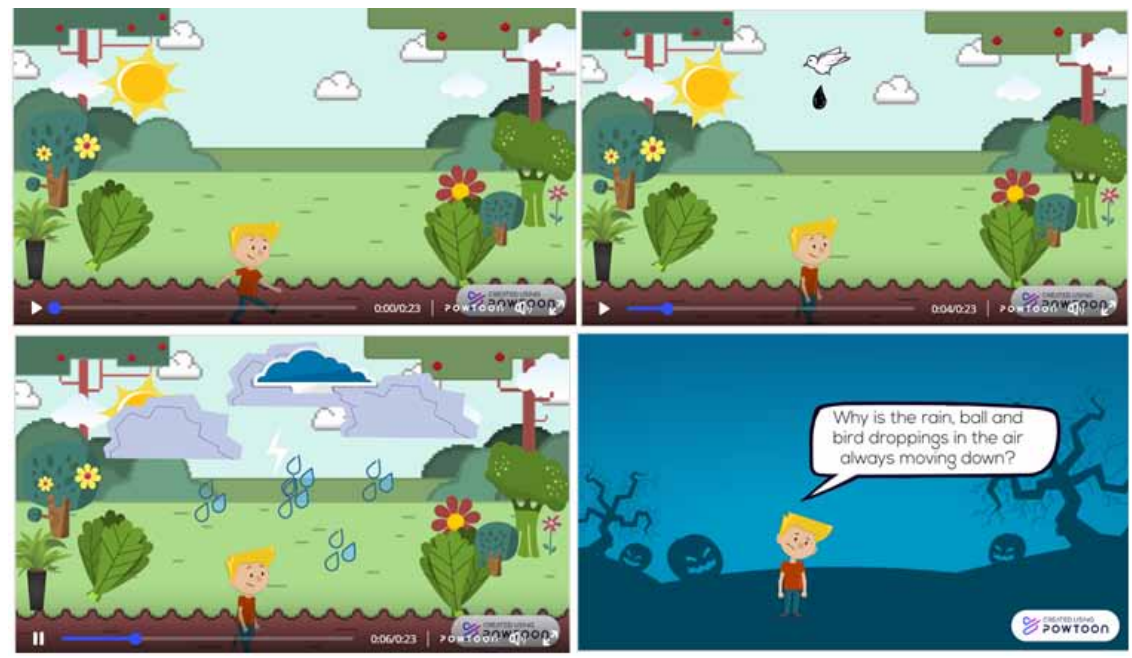

Figure 3. Weight experiment screenshot

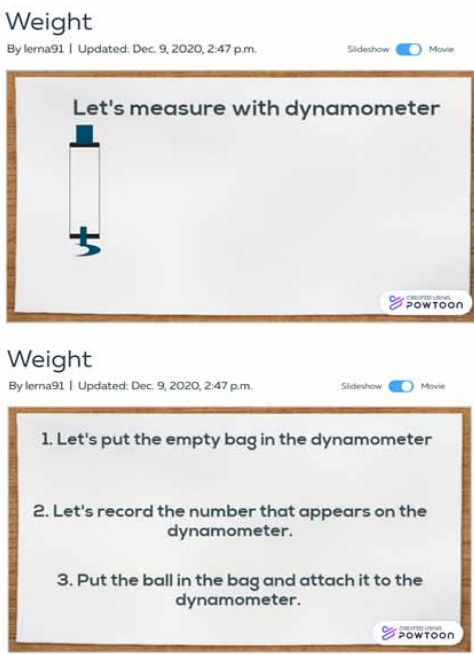

Weight
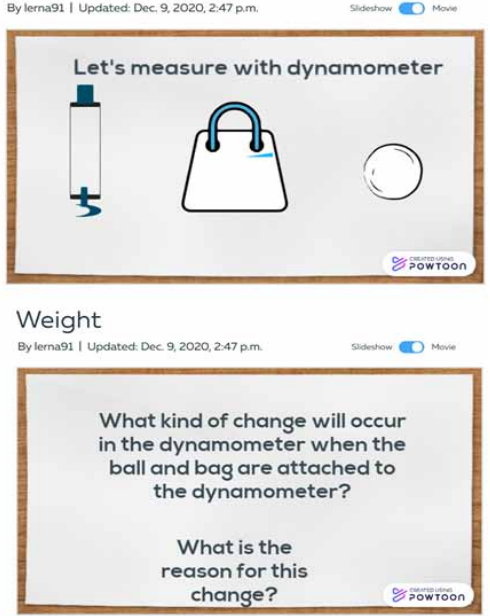

\section{Elaborate}

In the elaborate phase, first, click on the "Bear on a Diet" tab in the "Cartoons" section opens a page, where the cartoon is shown to the class. In this cartoon (Figure 5), students are shown that mass and weight are different concepts.

Finally, clicking one on the "Mass and Weight Differences" tab in the "Lecture" section opens a page (https://www.powtoon.com/c/bs5UhFRVVxd/0/m) including an animation (Figure 6) that aims to help students understand differences between the concepts of mass and weight, and a discussion is undertaken by asking questions about the subject. 
Figure 4. Screenshots of Prezi

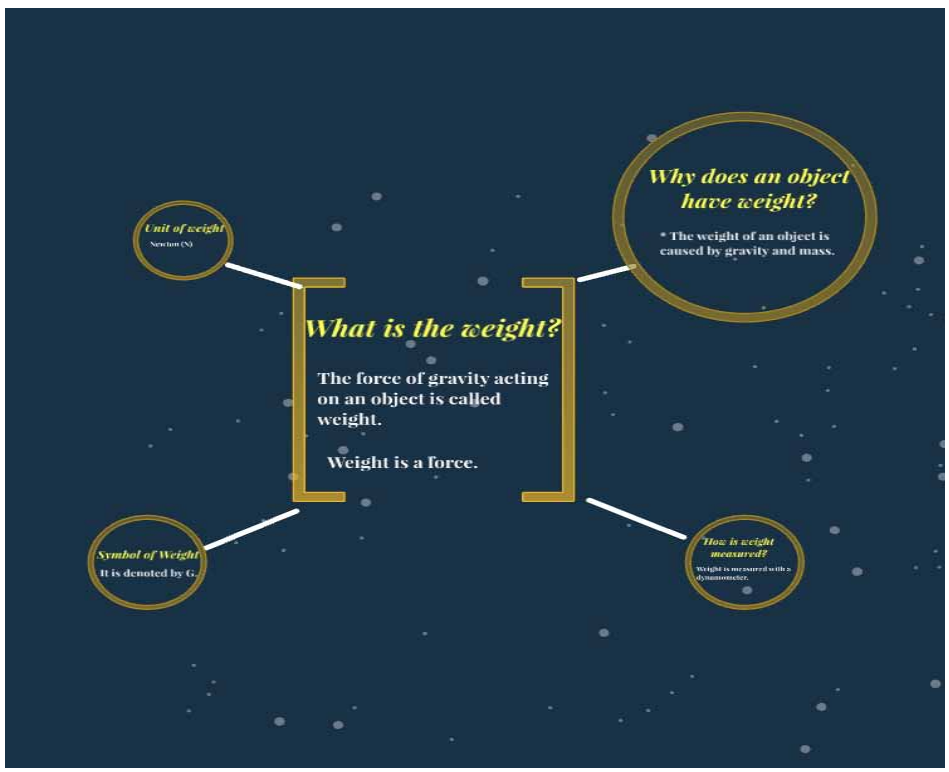

Figure 5. Screenshots of the bear on a diet cartoon
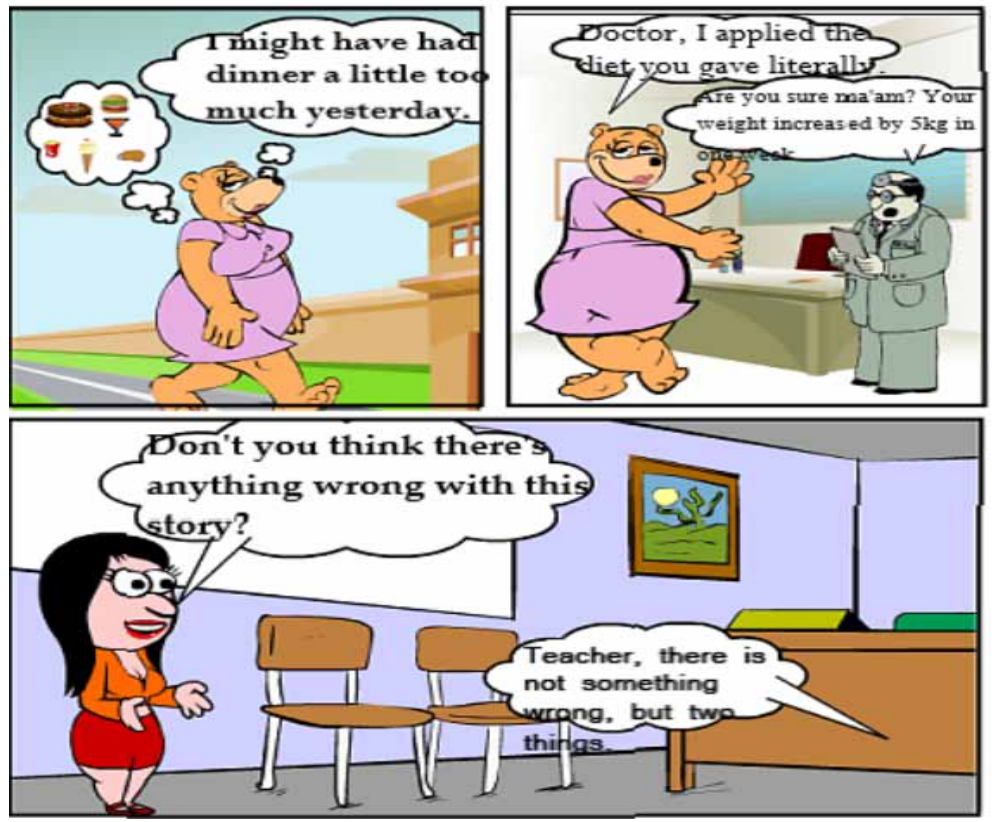


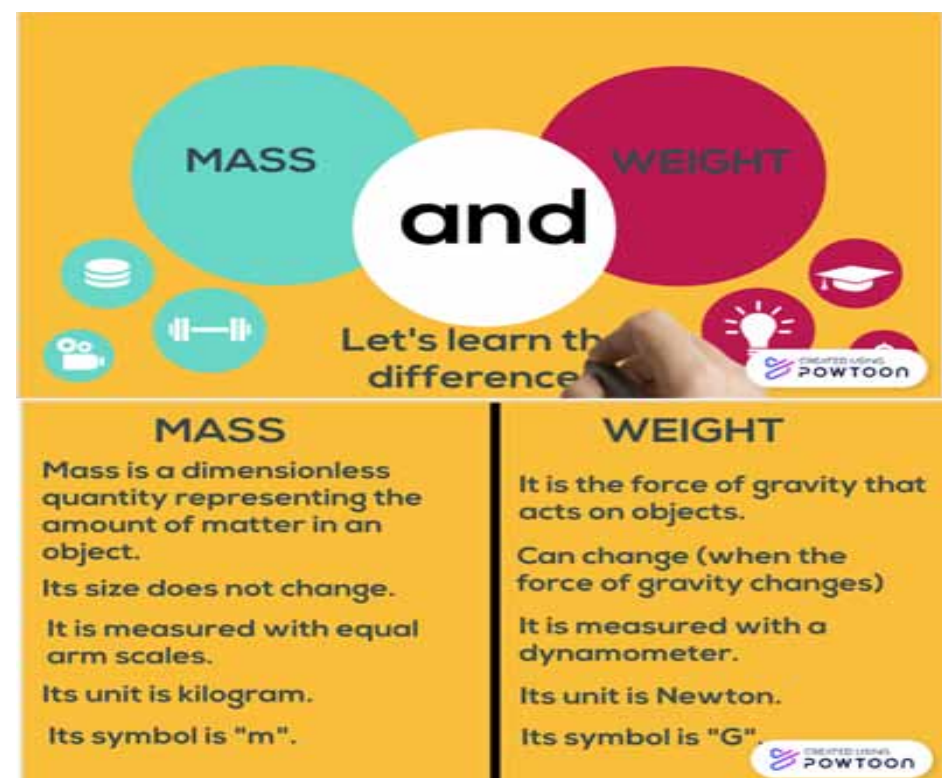

\section{Evaluate}

In the last (elaborate) phase, clicking on the "Kahoot" tab in the "Evaluation" section opens a page (https://play.kahoot.it/v2/lobby?quizId=5821ea3b-478e-4ad6-8093-74fa6b0c5b27), where students can connect to the application using their phone and answer questions about the subject. The student who gives the most correct answers to the questions in the shortest time wins the competition.

\section{Implementation Process Of The Control Group}

In the control group of the study, a science education program planned in accordance with the $5 \mathrm{E}$ learning model within the current curriculum was implemented. The same or similar activities were presented in the experimental group but in the control group, the activities did not use Web 2.0 tools. For both groups, textbooks, educational platforms, such as Morpa Campus and EBA system, drama, and discussion activities were also used.

\section{Instruments}

The academic achievement test (AAT) and the scale of Students' Motivation toward Science Learning (SMTSL) were used as the data collection tools.

\section{Academic Achievement Test (Aat)}

AAT consists of 26 multiple-choice questions. This test was improved by the researchers to measure the acquisitions of the "Force and Energy" unit of the seventh-grade science course based on Bloom's taxonomy. The questions in AAT were prepared using textbooks, supplementary resource books, and various websites. The questions in AAT were presented to experts for their views about the content validity. In order to assign the relevance measurable of each question in the test, the views of a field expert and two seventh-grade science teachers were taken. Consequently with the expert evaluations, the content validity of the test was confirmed. Then, the developed test was first applied to a group of eighth-grade students $(n=40)$. The discrimination and difficulty coefficients of the items for the test were calculated to maintain structure validity. The result of the item analyses showed that no item 
Table 2. Results of the Shapiro-Wilk normality test

\begin{tabular}{|c|c|c|c|c|}
\hline \multirow[t]{2}{*}{ Groups } & \multicolumn{4}{|c|}{ Shapiro-Wilk } \\
\hline & & Statistic & $\mathbf{N}$ & $\mathbf{p}$ \\
\hline \multirow[t]{2}{*}{ AAT- Pretest } & Experimental & 0.954 & 23 & 0.360 \\
\hline & Control & 0.954 & 25 & 0.300 \\
\hline \multirow[t]{2}{*}{ AAT- Posttest } & Experimental & 0.943 & 23 & 0.205 \\
\hline & Control & 0.936 & 25 & 0.121 \\
\hline \multirow[t]{2}{*}{ SMTSL- Pretest } & Experimental & 0.919 & 23 & 0.064 \\
\hline & Control & 0.971 & 25 & 0.673 \\
\hline \multirow[t]{2}{*}{ SMTSL- Posttest } & Experimental & 0.927 & 23 & 0.095 \\
\hline & Control & 0.939 & 25 & 0.140 \\
\hline
\end{tabular}

AAT: Academic Achievement Test

SMTSL: Scale of Students' Motivation toward Science Learning

Table 3. Results of the independent samples t-test for the comparison of the pretest and posttest AAT scores of the experimental and control groups

\begin{tabular}{|l|l|l|l|l|l|l|l|}
\hline \multicolumn{2}{|c|}{ Groups } & \multicolumn{1}{c|}{ N } & & \multicolumn{1}{c|}{ SD } & \multicolumn{1}{c|}{ df } & \multicolumn{1}{c|}{ t } & \multicolumn{1}{c|}{ p } \\
\cline { 1 - 7 } AAT-Pretest & Experimental & 23 & 5.22 & 2.645 & 22 & -0.197 & 0.845 \\
\cline { 2 - 6 } & Control & 25 & 5.36 & 2.378 & 24 & & \\
\hline \multirow{2}{*}{ AAT-Posttest } & Experimental & 23 & 17.69 & 4.247 & 22 & 2.763 & \multirow{2}{*}{0.008} \\
\cline { 2 - 6 } & Control & 25 & 14.28 & 4.306 & 24 & \\
\hline
\end{tabular}

AAT: Academic Achievement Test

Table 4. Paired samples t-test results between pretest-posttest scores of AAT

\begin{tabular}{|l|l|l|l|l|l|l|l|}
\hline \multicolumn{2}{|c|}{ Groups } & \multicolumn{1}{c|}{ N } & & \multicolumn{1}{c|}{ SD } & \multicolumn{1}{c|}{ df } & \multicolumn{1}{c|}{ t } & \multicolumn{1}{c|}{ p } \\
\cline { 1 - 7 } Experimental & Pretest & 23 & 5.22 & 2.645 & 22 & -11.275 & 0.00 \\
\cline { 2 - 7 } & Posttest & 23 & 17.69 & 4.247 & 22 & & \multirow{2}{*}{0.00} \\
\cline { 1 - 6 } Control & Pretest & 25 & 5.36 & 2.378 & 24 & \\
\cline { 2 - 6 } & Posttest & 25 & 14.28 & 4.306 & 24 & \\
\hline
\end{tabular}

should be removed from AAT, which was considered to be difficult and discriminative at a medium level. Finally, a valid and reliable AAT was developed by researchers for the "Force and Energy" unit consisting of 26 items, each with four choices. The KR-20 reliability coefficient of AAT was 0.82 .

\section{Scale Of Students' Motivation Toward Science Learning (Smtsl)}

In the research, SMTSL, developed by Dede and Yaman (2008), was used to measure the students' motivation toward science learning. The Cronbach alpha reliability coefficient of the scale was found to be .80 SMTSL consists of 23 items based on a five-point Likert-scale (Dede \& Yaman, 2008, p. 
Table 5. Results of the independent samples t-test for the comparison of the pretest SMTSL scores of the experimental and control groups

\begin{tabular}{|l|l|l|l|l|l|l|l|}
\hline \multicolumn{2}{|c|}{ Groups } & \multicolumn{1}{c|}{ N } & & \multicolumn{1}{c|}{ SD } & \multicolumn{1}{c|}{ df } & \multicolumn{1}{c|}{ t } & p \\
\hline \multirow{2}{*}{ SMTSL pretest } & Experimental & 23 & 98.65 & 8.271 & 22 & 2.901 & 0.006 \\
\cline { 2 - 7 } & Control & 25 & 90.44 & 11.011 & 24 & & \\
\hline
\end{tabular}

Table 6. Results of the descriptive statistics of the posttest SMTSL scores according to the groups

\begin{tabular}{|l|l|l|l|}
\hline \multicolumn{1}{|c|}{ Groups } & \multicolumn{1}{c|}{ N } & & \multicolumn{1}{c|}{ SD } \\
\hline Experimental & 23 & 98.36 & 10.459 \\
\hline Control & 25 & 88.16 & 11.629 \\
\hline
\end{tabular}

19). In this scale, 21 items are positive and two (items 17 and 18) are negative, and the alpha value was calculated as 0.86 .

\section{Data Analysis}

The data obtained from the research were analyzed using quantitative methods. The analysis of the data was performed by exploring descriptive statistics with SPSS version 17. The Shapiro-Wilk normality analysis can be used if the sample size is smaller than 50 (Büyüköztürk, 2005). When the normality distributions of the data were examined, all the data were identified to be normally distributed. The results are summarized in Table 2 . Since the tests have a significance value of $p>0.05$; it was seen to be a normal distribution; therefore, the data should be analyzed with parametric tests.

\section{FINDINGS}

\section{FINDINGS ON AAT}

The independent samples t-test was conducted to determine the differences between the two groups before the implementation, and the results are given in Table 3.

The data in Table 3 reveals no significant difference in the AAT pretest scores $(t=-0.197 ; p>$ $0.05)$ of the two groups. Consequently, it was seen that the achievements of groups were the same prior to the implementation process. Therefore, it was decided to analyze the AAT posttest scores of the groups using the independent samples t-test as summarized in Table 3 too. Table 3 reveals a statistically significant difference group in the AAT scores of both groups in favor of the experimental group $(\mathrm{t}=2.763 ; \mathrm{p}<0.05)$.

Table 7. ANCOVA results of the posttest scores corrected according to the pretest SMTSL scores

\begin{tabular}{|l|l|l|l|l|l|}
\hline \multicolumn{1}{|c|}{ Source of variance } & Sum of squares & \multicolumn{1}{|c|}{ df } & \multicolumn{1}{|c|}{ Mean square } & \multicolumn{1}{|c|}{ F } & p \\
\cline { 1 - 5 } Pretest (reg.) & 815.336 & 1 & 815.336 & 7.591 & .008 \\
\hline Group & 454.895 & 45 & 454.895 & 4.235 & .045 \\
\cline { 1 - 3 } Error & 4833.503 & 45 & 107.411 & & \\
\hline
\end{tabular}


Table 8. Results of the paired samples t-test for the comparison of the pretest and posttest SMTSL scores

\begin{tabular}{|l|l|l|l|l|l|l|l|}
\hline \multicolumn{2}{|c|}{ Groups } & \multicolumn{1}{c|}{ N } & & \multicolumn{1}{c|}{ SD } & \multicolumn{1}{c|}{ df } & \multicolumn{1}{c|}{ t } & \multicolumn{1}{c|}{ p } \\
\cline { 1 - 7 } Experimental & Pretest & 23 & 98.65 & 8.271 & 22 & 0.180 & 0.859 \\
\cline { 2 - 7 } & Posttest & 23 & 98.39 & 10.452 & 22 & \\
\hline \multirow{2}{*}{ Control } & Pretest & 25 & 90.44 & 11.012 & 24 & 0.774 & 0.447 \\
\cline { 2 - 6 } & Posttest & 25 & 88.16 & 11.629 & 24 & \\
\hline
\end{tabular}

The paired samples t-test results were also undertaken to determine whether there was a significant difference between the pretest posttest AAT scores within both the experimental and control groups. The results indicated a statistically significant difference in the pretest and posttest AAT scores in favor of the latter for both the experimental $(\mathrm{t}=-11.275 ; \mathrm{p}<0.05)$ and control $(\mathrm{t}=-10.514 ; \mathrm{p}<$ $0.05)$ groups (Table 4).

\section{Findings On Smtsl}

The independent samples t-test was also used to determine the differences between the two groups concerning the students' motivation toward science learning before the implementation, and the results are given in Table 5 .

There was a significant difference between the SMTSL pretest scores of the experimental and control groups $(\mathrm{t}=2.901 ; \mathrm{p}<0.05)$. Accordingly, prior to the application, there was no equivalence in the motivation of the groups toward science learning. Therefore, it was decided that the posttest SMTSL scores of the groups should be analyzed using one-factor ANCOVA, and the descriptive statistical scores of the motivation levels of the groups are shown in Table 6.

Table 6 shows that the mean posttest SMTSL scores were $X=98.36(\mathrm{SD}=10.459)$ for the experimental group $\mathrm{X}=88.16(\mathrm{SD}=11.629)$ for the control group.

According to the ANCOVA results, a significant difference was determined in the motivation toward science learning between the mean posttest scores of the experimental and control groups in favor of the experimental group $[\mathrm{F}(1-47)=4.235, \mathrm{p}<0.05]$. Thus, it can be stated that the science lesson enriched with Web 2.0 tools was effective in increasing the students' motivation toward science learning.

The dependent t-test results in Table 8 show whether there was a significant difference between the pretest posttest SMTSL scores within both the experimental and control groups. According to these results, there was no statistically significant difference for motivation toward science learning between the pretest and posttest scores of the experimental $(\mathrm{t}=0.180 ; \mathrm{p}>0.05)$ and control $(\mathrm{t}=$ $0.447 ; \mathrm{p}>0.05)$ groups.

\section{CONCLUSION}

On completion of the study, when the total AAT scores of the students were examined, the mean AAT scores of the experimental group were higher at a statistically significant level. At the same time, the SMTSL scores of the students revealed that the means scores of the students in the experimental group were significantly statistically higher.

As a result of the analysis concerned with the question of the research, there was a significant difference between the academic achievement of the experimental group, supported by Web 2.0 tools and the control group of students who were not supported by those tools. Accordingly, it was observed that using Web 2.0 tools in science education had a positive effect on the students' academic achievement. However, when the pretest and posttest AAT scores of the students were compared within the experimental and control groups, there was a statistically significant difference in favor of the 
posttest scores for both groups. In other words, the science teaching performed increased academic achievement in both groups, but the AAT averages of the students in the experimental group were significantly higher than those of the control group students.

The literature contains many studies supporting the results of the current study: in terms of the significant impact of web-based science teaching on student achievement; e.g., the use of Web 2.0 tools in physics teaching (Baig, 2011), a science teaching design prepared in the web environment (Bayrak Karadeniz \& Bayram, 2012; Karagöz \& Korkmaz 2015), science teaching supported by technology (Akgün, Özden, Çinici, Aslan \& Berber, 2014), science teaching supported by WebQuest (Ballıel Ünal, 2017), web-based science teaching prepared according to the multimedia design model (Çetin \& Günay, 2010), adaptive educational web environments (Güngören Canan, 2019), web-supported teaching materials suitable for a brain-based learning approach (Şenel Çoruhlu, Er Nas \& Keleş (2016), computer-aided education software (Buluş Kırıkkaya, Dağ, Durdu \& Gerdan, 2016; Kölemen, 2020), web-based science education (Can, 2008; Ercan, Bilen, \& Bulut, 2013), a problem-based learning method supported by Web 2.0 tools (Hursen, 2020). In addition, Ergul Sonmez and Cakir (2021) also analyzed the contributions of wikis and blogs, which are accepted as web 2.0 technologies, to academic performance using meta-analysis method. As a result of the study, it shows that the effect of web 2.0 technologies on academic performance is positive and medium.

As a result of the analysis related to the students' motivation for learning science, a significant difference was found between the experimental group and control group students' motivation for learning science in favor of the former. Accordingly, the effect of science teaching supported by Web 2.0 tools on students' motivation to learn science was greater than the current curriculum without Web 2.0 tools. However, when the pretest and posttest SMTSL scores of the students in both the control and experimental groups were compared, there was no significant difference. In this study, the motivation scale scores decreased in the experimental group and control group in their post-tests. It was considered that students' motivation may have decreased because they had difficulty in learning the content of "Force and Energy" unit. In the literature, similar studies found that students had problems with comprehending the topic of Force. In a study by Kahraman (2013) on the "Force and Motion" unit, a decrease was seen in the posttest motivation scores of the control and experimental groups compared to the pretest scores, as found in our study. Examining the literature on determining the effect of Web 2.0 tools on student motivation, it was seen that students' motivation toward science learning increased. Furthermore, web-based education with blended learning (Akgündüz \& Akınoğlu, 2017; Balaman \& Tüysüz, 2011), lessons enriched with Web 2.0 tools (Karahan \& Roehrig, 2016), and web-based learning environments (Wang \& Reeves, 2007) had a positive effect on student motivation. The students are easily motivated and engaged by technology (Kalogiannakis, Nirgianaki \&Papadakis, 2018). The results of research show that the website enriched by web 2.0 tools for teaching natural sciences is effective, motivating, exciting, and amusing for pupils.

When the results of the studies on WEB 2.0 tools in the literature are examined, it is seen that there are positive opinions about their use in teaching. According to this; Kimav and Aydin (2020) show that as a result of the data they gathered from both students and teachers, both groups appreciate technology integration in English lessons. Ozcinar et al. (2020) stated in their study that pre-service teachers wanted to using web 2.0 tools for reinforcement in learning and to draw attention to the subject. In addition, Isaías, Miranda and Pífano (2020) also stated in their studies that the use of Web 2.0 tools in higher education is effective in factors such as technology selection, user-friendly tools, student participation, high number of active students, access to relevant content and communication.

The COVID-19 pandemic, which started in December 2019 and has continued unabated, resulting in many existing education systems around the world being suspended. In this process, a search for alternative to face-to-face education has begun. It is observed that education continues, especially with online training. As the results of this study show, this alternative may be an educational website supplemented with Web 2.0 tools, which has positive effects on learning and motivation.

At the results of this study the following suggestions are given; 
- This research was conducted by activities prepared with Web 2.0 tools according on the 5E learning cycle model. Researches can be carried out on the using of Web 2.0 tools with other learning models.

- This study was carried out at middle school level, it can be conducted at elementary and high school level too

- This study was carried out at science lesson, it can be conducted at different lessons too.

\section{ACKNOWLEDGMENT}

This article is derived from Lerna Gürleroğlu's master dissertation entitled "Investigation of the effect of science teaching on student achievement, attitude to motivation and digital literacy performed with web 2.0 applications suitable for 5E model" which was conducted under the supervision of Mehtap Yildirim. 


\section{REFERENCES}

Akgün, A., Özden, M., Çinici, A., Aslan, A., \& Berber, S. (2014). Teknoloji destekli öğretimin bilimsel süreç becerilerine ve akademik başarıya etkisinin incelenmesi [An investigation of the effect of technology based education on scientific process skills and academic achievement]. Electronic Journal of Social Sciences, 13(48), 27-46. doi:10.17755/esosder.97729

Akgündüz, D., \& Akınoğlu, O. (2017). Fen eğitiminde harmanlanmış öğrenme ve sosyal medya destekli öğrenmenin öğrencilerin akademik başarılarına ve motivasyonlarına etkisi [The impact of blended learning and social media-supported learning on the academic success and motivation of the students in science education]. Education in Science, 42(191), 69-90.

Baig, M. A. (2011). A critical study of effectiveness of online learning on students' achievements. I-Manager's Journal of Educational Technology, 7(4), 28-34. https://www.semanticscholar.org/paper/A-Critical-Study-ofEffectiveness-of-Online-on-Baig/4e590d5f3ee8f9c62c26cfa8d55d2c5dd7b36388

Balaman, F., \& Tüysüz, C. (2011). Harmanlanmış öğrenme modelinin 7. sınıf öğrencilerinin fen ve teknoloji dersindeki başarılarına, tutumlarına ve motivasyonlarına etkisinin incelenmesi [Researching the effect of blended learning model on the science and technology course success, attitudes and motivations of $7^{\text {th }}$ class students]. The Western Anatolia Journal of Educational Sciences, 2(4), 75-90.

Ballıel Ünal, B. (2017). Web tabanlı uzaktan eğitimin fen bilimleri konularında öğrenci başarısına etkisi [Effect of web-based distance education on student achievement in science education]. International Journal of Turkish Education Sciences, 5(9), 481-490.

Bayrak Karadeniz, B., \& Bayram, H. (2012). Web ortamında probleme dayalı̈ ögrenme yönteminin farklı öğrenme stiline sahip öğrencilerin akademik başarılarına etkisi [The effect of problem-based learning in a web environment on the academic achievement of students with different learning styles]. Mustafa Kemal University Journal of Graduate School of Social Sciences, 9(18), 479-497.

Buluş Kırıkkaya, E., Dağ, F., Durdu, L., \& Gerdan, S. (2016). 8. sınıf doğal süreçler ünitesi için hazırlanan BDÖ yazılımı ve akademik başarıya etkisi [CAI software for 8th grade natural processes unit and its effect on academic success]. Elementary Education Online, 15(1), 234-250. doi:10.17051/io.2016.11845

Büyüköztürk, Ş. (2005). Sosyal bilimler için veri analizi el kitabı istatistik, araştırma deseni SPSS uygulamaları ve yorum [Data analysis handbook for social sciences statistics, research design SPSS applications and interpretation]. Pegem Akademi.

Büyüköztürk, Ş., Kılıç Çakmak, E., Akgün, Ö. E., Karadeniz, Ş., \& Demirel, F. (2013). Bilimsel araştırma yöntemleri [Scientific research methods]. Pegem Akademi.

Bybee, R. W. (2009). The BSCS $5 E$ instructional model and 21st century skills. Retrieved from https://sites. nationalacademies.org/cs/groups/dbassesite/documents/webpage/dbasse_073327.pdf

Can, Ş. (2008). Fen eğitiminde web tabanl öğretim [Web based instruction in science teaching] [Unpublished master thesis]. Celal Bayar University, Institute of Natural Sciences, Manisa.

Çekinmez, M. (2009). Web 2.0 teknolojileri ve açık kaynak kodlu öğretim yönetim kullanılarak uzaktan ĕ̆itim sistemi uygulanmast [An e-learning application using web 2.0 technologies and open source learning management systems] [Unpublished master thesis]. Sakarya University, Institute of Natural Sciences, Sakarya, Turkey.

Çetin, O., \& Günay, Y. (2010). Fen eğitiminde web tabanlı öğretimin öğrencilerin akademik başarılarına ve tutumlarına etkisi [The effect of web-based teaching on students' academic achievement and attitudes in science education]. Çukurova University Faculty of Education Journal, 38(3), 19- 34.

Chen, T., Peng, L., Yin, X., Rong, J., Yang, J., \& Cong, G. (2020). Analysis of user satisfaction with online education platforms in china during the covid-19 pandemic. Health Care, 8(200), 1-26. doi:10.3390/ healthcare8030200 PMID:32645911

Cin Seker, Z. (2020). The effect of web 2.0 educational tools on the success of secondary school 5th grade students in affix-root teaching. European Journal of Alternative Education Studies, 5(1), 95-107. doi:10.5281/ zenodo. 3758588

Cohen, L., Manion, L., \& Morrison, K. (2000). Research methods in education (5th ed.). Routledge Falmer. 
Creswell, J. W. (2008). Educational research planning, conducting and evaluating quantitative and qualitative research. International Pearson Merril Prentice Hall.

Dede, Y., \& Yaman, S. (2008). Fen öğrenmeye yönelik motivasyon ölçeği: Geçerlik ve güvenlik çalışması [A questionnaire for motivation toward science learning: A validity and reliability study]. Necatibey Faculty of Education Electronic Journal of Science and Mathematics Education, 2(1), 19-37. https://dergipark.org.tr/tr/ download/article-file/39760

Dinc, E. (2017). Web-based education and accessibility. International Journal of Technology in Education and Science, 1(1), 29-35. https://www.ijtes.net/index.php/ijtes/article/view/4/3

Drexler, W., Baralt, A., \& Dawson, K. (2008). The teach web 2.0 consortium: A tool to promote educational social networking and web 2.0 use among educators. Educational Media International, 45(4), 271-283. doi:10.1080/09523980802571499

Duran, L. B., \& Duran, E. (2004). The 5E instructional model: A learning cycle approach for inquiry-based science teaching. The Science Education Review, 3(2), 49-58.

Durovic, G., Dlab, M. H., \& Hoic-Bozic, N. (2018). Motivating STEM students to use Web 2.0 tools for learning: A case study, 2018 International Conference on Information Management and Processing (ICIMP), 140-144. doi:10.1109/ICIMP1.2018.8325856

Elmas, R., \& Geban, Ö. (2012). Web 2.0 tools for $21^{\text {st }}$ century teachers. International Online Journal of Educational Sciences, 4(1), 243-254.

Ercan, O., Bilen, K., \& Bulut, A. (2013). The effect of web-based instruction with educational animation content at sensory organs subject on students' academic achievement and attitudes. Procedia: Social and Behavioral Sciences, 116, 2430-2436. doi:10.1016/j.sbspro.2014.01.587

Ergul Sonmez, E., \& Cakir, H. (2021). Effect of Web 2.0 technologies on academic performance: A meta-analysis study. International Journal of Technology in Education and Science, 5(1), 108-127. doi:10.46328/ijtes.161

Genç, H. (2010). Internetteki etkileşim merkezi sosyal ağlar ve e-iş 2.0 uygulamaları [Social network as an interactivity center of the internet and applications of E-business 2.0]. Akademik Bilisim Konferansı, Muğla, 12, 481-487. https://ab.org.tr/ab10/kitap/genc_e-is_AB10.pdf

Güngören Canan, Ö. (2019). The effects of adaptive educational web environment on students' academic achievement and motivation. Kastamonu Education Journal, 27(3), 1311-1326. doi:10.24106/kefdergi.3079

Halili, S. H. (2018). Emerging trends of web 2.0 tools in adult education. The Online Journal of Distance Education and e-Learning, 6(2), 55-60. https://www.tojdel.net/journals/tojdel/articles/v06i02/v06i02-09.pdf

Huang, W. D., Hood, D. W., \& Yoo, S. J. (2013). Gender divide and acceptance of collaborative Web 2.0 applications for learning in higher education. The Internet and Higher Education, 16, 57-65. doi:10.1016/j. iheduc.2012.02.001

Hursen, C. (2020). The effect of problem-based learning method supported by web 2.0 tools on academic achievement and critical thinking skills in teacher education. Tech Know Learn. 10.1007/s10758-020-09458-2

Isaías, P., Miranda, P., \& Pifano, S. (2020). Framework for Web 2.0 implementation in higher education: Experts' validation. Higher Education Quarterly, hequ.12295. Advance online publication. doi:10.1111/hequ.12295

Kahraman, Ö. (2013). Dijital hikâyecilik metoduyla hazırlanan öğretim materyallerinin öğrenme döngüsü giriş aşamasında kullanılmasının fizik dersi başarısı ve motivasyonuna etkisi [The effect of using teaching materials prepared by digital storytelling method at the engagement of learning cycle on physics course achievement and motivation level] [Unpublished Doctoral dissertation]. Balıkesir University, Institute of Natural Sciences, Balıkesir, Turkey.

Kaldoudi, E., Bamidis, P., Papaioakeim, M., \& Vargemezis, V. (2008). Problem-based learning via web 2.0 technologies. 2008 21st IEEE International Symposium on Computer-Based Medical Systems, 391-396. doi:10.1109/CBMS.2008.136

Kalogiannakis, M., Nirgianaki, G. M., \& Papadakis, S. (2018). Teaching magnetism to preschool children: The effectiveness of picture story reading. Early Childhood Education Journal, 46(5), 535-546. doi:10.1007/ s10643-017-0884-4 
Karagöz, F., \& Korkmaz, S. D. (2015). Fen ve teknoloji dersinde web destekli öğretim yönteminin 7. sınıf öğrencilerinin akademik başarılarına ve öğrendikleri bilgilerin kalıcılığına etkisi [The effect of web based teaching method on $7^{\text {th }}$ Grade student achievement and retention of knowledge in a science and technology lesson]. International Periodical for the Languages, Literature and History of Turkish, 10(11), 927-948.

Karahan, E., \& Roehrig, G. (2016). Use of web 2.0 technologies to enhance learning experiences in alternative school settings. International Journal of Education in Mathematics, Science and Technology, 4(4), $272-283$. doi:10.18404/ijemst.32930

Kimav, A. U., \& Aydın, B. (2020). A Blueprint for In-Service Teacher Training Program in Technology Integration. Journal of Educational Technology \& Online Learning, 3(3), 224-244. doi:10.31681/jetol.761650

Kölemen, S., \& Hacieminoğlu, E. (2020). Araştırma-sorgulama ve bilgisayar destekli öğretim [Inquiry and WEB based education]. Iksad Publications.

Konstantinidis, A., Theodosiadou, D., \& Pappos, C. (2013). Web 2.0 tools for supporting teaching. Turkish Online Journal of Distance Education-TOJDE, 14(4), 287-295.

Mališů, P., \& Šaloun, P. (2020). Multimedia and interactivity in educational materials. Technium Social Sciences Journal, 13(1), 47-50. doi:10.47577/tssj.v13i1.1818

MoNE. (2018). Science lesson curriculum (Primary and secondary school 3, 4, 5, 6, 7 and 8th grades) [Fen bilimleri dersi ögretim programı (Ilkokul ve ortaokul 3, 4, 5, 6, 7 ve 8. sinıflar)]. MEB.

Moshahid, M., \& Pt, A. (2017). A study on awareness of web 2.0 resources in education among B.ed students. International Journal of Academic Research and Development, 2(3), 158-162. http://www.academicjournal.in/ search?keyword=A+study+on+awareness+of+web+

OleaM. D. (2019). Application of Web 2.0 tools in teaching 21st-century students in higher education in Calabarzon, Philippines. IOER International Multidisciplinary Research Journal, 1(1), 1-8. https://ssrn.com/ abstract $=3347435$

Ozcinar, Z., Sakhieva, R., Pozharskaya, E., Popova, O., Melnik, M., \& Matvienko, V. (2020). Student's Perception of Web 2.0 Tools and Educational Applications. International Journal of Emerging Technologies in Learning, 15(23), 220-233. doi:10.3991/ijet.v15i23.19065

Özenç, M., Dursun, H., \& Şahin, S. (2020). The effect of activities developed with web 2.0 tools based on the 5E learning cycle model on the multiplication achievement of $4^{\text {th }}$ graders. Participatory Educational Research, 7(3), 105-123. doi:10.17275/per.20.37.7.3

Peltier-Davis, C. (2009). Web 2.0, library 2.0, library user 2.0, librarian 2.0: Innovative services for sustainable libraries. Computers in Libraries, 29(10), 16-21.

Rajab, M. H., Gazal, A. M., \& Alkattan, K. (2020). Challenges to online medical education during the covid-19 pandemic. Cureus, 12(7), e8966. doi:10.7759/cureus.8966 PMID:32766008

Redecker, C., Ala-Mutka, K., \& Punie, Y. (2008). Learning 2.0 - The use of social computing to enhance lifelong learning. Conference: EADTU Annual Conference, Poitiers, France. Available from: https://www.researchgate. net/publication/256461666_Learning_20_-_the_use_of_social_computing_to_enhance_lifelong_learning

Şenel Çoruhlu, T., Er Nas, S., \& Keleş, E. (2016). Beyin temelli öğrenme yaklaşımına dayalı web destekli öğretim materyalinin etkililiğinin değerlendirilmesi: Işık ve ses ünitesi [Evaluation of Efficacy the Web Based Instructional Material Prepared according to Brain Based Learning Approach: "Light and Sound" Unit]. Amasya Education Journal, 5(1), 104-132. doi:10.17539/aej.79756

Ureña-Torres, J., Tenesaca-Luna, G., Arciniegas, M. B. M., \& Segarra-Faggioni, V. (2017). Collaborative and active learning through web 2.0 tools applied in higher education. 2017 12th Iberian Conference on Information Systems and Technologies (CISTI), 1-7. doi:10.23919/CISTI.2017.7975709

Wang, S., \& Reeves, T. C. (2007). The effects of a web-based learning environment on student motivation in a high school earth science course. Educational Technology Research and Development, 55(2), $169-192$. doi:10.1007/s11423-006-9016-3

Wijekumar, K. (2005). Creating effective web-based learning environments: relevant research and practice. Innovate: Journal of Online Education, 1(5). https://www.learntechlib.org/p/107287/ 
Mehtap Yildirim is a professor in Science Education Department at Marmara University in Turkey. Yıldırım's research interest is in the area of science education particularly on teaching and learning approaches and teaching and learning practices. She is an active professor and researcher and published a number of research articles on science education. ORCID ID: http://orcid.org/0000-0001-7398-8396

Lerna Gurleroglu is a science teacher at the secondary school and research in the area of science education particularly on used web 2.0 tools in education. She is an active teacher and researcher. ORCID ID: https://orcid. org/0000-0002-6511-0863 